\title{
Ryder's Painism and His Criticism of Utilitarianism
}

\author{
Joost Leuven - Tatjana Višak
}

Accepted: 7 February 2012/Published online: 23 February 2012

(C) The Author(s) 2012. This article is published with open access at Springerlink.com

\begin{abstract}
As a member of the British Oxford Group, psychologist Richard Ryder marked the beginning of the modern animal rights and animal welfare movement in the seventies. By introducing the concept "speciesism." Ryder contributed importantly to the expansion of this movement. Surprisingly little attention has been paid to Ryder's moral theory, "painism", that aims to resolve the conflict between the two predominant rival theories in animal ethics, the deontological of Tom Regan and the utilitarian of Peter Singer. First, this paper examines the kernel and historical sources of Ryder's painist theory, linking it to the work of John Rawls and Jean-Jacques Rousseau. Second, it examines Ryder's critique of utilitarianism. It is argued that his critique of Singer's use of the word "sentience" is unconvincing and that his critique of utilitarian aggregation as not taking a full account of the metaphysical separateness of persons, has already been countered and dealt with. Finally this paper looks at some of the counterintuitive implications of Ryder's theory and argues that utilitarianism might have more resources for dealing with its own alleged counterintuitive implications than Ryder acknowledges.
\end{abstract}

Keywords Richard Ryder · Painism · Animal ethics · Utilitarianism · Aggregation

\footnotetext{
J. Leuven

Leiden, The Netherlands

e-mail: jleuven@gmail.com

T. Višak (ه)

Ethics Institute, Utrecht University, Janskerkhof 13 A, room 1.06, 3512 BL Utrecht,

The Netherlands

e-mail: t.visak@uu.nl
} 


\section{Introduction}

As a member of the British Oxford Group psychologist, Richard Ryder marked the beginning of the modern animal rights and animal welfare movement in the seventies. By introducing the concept "speciesism", Ryder contributed importantly to the expansion of this movement. It cleared the way for a movement that could identify its aims with those of previous liberation movements, such as those of women, black people, and homosexuals, and thereby distinguish itself from movements that have been concerned with animal welfare since the eighteenth century (Cavalieri 2010; Kean 1998; Ryder 1989).

Richard Dawkins and Peter Singer, among others, popularized the term "speciesism", which analogous to "sexism" and "racism" refers to morally unjustified discrimination, in this case on the basis of a being's species. Mainly due to the work of those writers, the term and the movement became well known among a broader public. Even though Ryder kept publishing about this subject, his view on animal ethics has been mostly neglected in the modern public discourse on animal ethics, which is dominated by debates between the major rival theories, the deontological by Tom Regan and the utilitarian by Peter Singer (Cavalieri 2010; Dawkins 1989; Francione 1996; Regan 1983; Ryder 1989, 2001; Singer 1975, 1979).

Ryder, who played a role in forming the current British laws about animal experimentation (Ryder 1999), remarked in the nineties that there is a double standard in laws that protect people on the one hand and non-human animals (henceforth 'animals') on the other hand (Ryder 2001). Laws that aim at the protection of humans in this area focus on rights of the individual. In case of animals, in contrast, the focus is on the avoidance of "unnecessary suffering", which is understood as excessive pain that is not necessary for continuing the form of animal use in question. According to Ryder, the moral considerations concerning animals are usually based on utilitarian calculations of costs and benefits: animal use is considered justified if the gains for the humans are larger than the costs to the animals. Therefore, according to Ryder, human interests are absolutely protected by law, while animal interests are not. Ryder considers this double standard in considering human and animal interests a form of speciesism. Ryder introduced the new term "painism" and his non-speciesist ethical theory in an effort to keep the worthwhile aspects of Singer's utilitarianism, while at the same time protecting the interests of the individual. On the other side of the ethical spectrum, Ryder wishes to steer free of Regan's rights theory. Ryder's aim is to present an improved moral theory, in between Singer's utilitarianism and Regan's rights theory, which is able to dissolve conflict between those rival theories.

Surprisingly little attention has been paid to Ryder's painism and his criticism of the other theories. While Ryder's painism is sometimes mentioned, seldom more than a paragraph is devoted to it. An example is Francione (1996), who writes:

Painism, a doctrine developed by Richard Ryder, purports to combine rightsand utility-type considerations by combining 'Singer's emphasis upon pain with Regan's concern for the individual.' [...] Ryder recognizes that even if consequential considerations play a role in a theory, that theory must provide 
for protecting interests beyond the interest in avoiding pain and suffering and must respect those interests that are constitutive of an 'individual'. (Francione 1996, p. 224)

This paper deals with Ryder's painism and his criticism of utilitarianism. We present the kernel and historical sources of Ryder's painist theory, and bring forward his main points or critique against utilitarianism. Then we discuss what we see as the major problems with Ryder's painism, in particular as compared to utilitarianism.

\section{The Basis for Painism: Rousseau, Rawls, and Ryder}

Ryder (2010) defines painism as:

[...] the theory that moral value is based upon the individual's experience of pain (defined broadly to cover all types of suffering whether cognitive, emotional, or sensory), that pain is the only evil, and that the main moral objective is to reduce the pain of others, particularly that of the most affected victim, the maximum sufferer. (Ryder 2010, p. 402)

Painism implies three central claims: (1) the ability to feel pain determines whether a being deserves moral consideration, (2) pain is the sole ultimate bad, and (3) improving the situation of the being that suffers most pain has moral priority. Ryder leads back those claims to the work of Jean-Jacques Rousseau and John Rawls (Ryder 1989, 2010).

Ryder (1989) traces back the claim that animals deserve our moral consideration because of their ability to feel pain to the work of Rousseau, who wrote in 1755 about the suffering of animals:

Il semble, en effet, que si je suis obligé de ne faire aucun mal à mon semblable, c'est moins parce qu'il est un être raisonnable que parce qu'il est un être sensible; qualité qui, étant commune à la bête et à l'homme, doit au moins donner à l'une le droit de n'être point maltraitée inutilement par l'autre.

(Rousseau 1755, p. 126)

It is remarkable that Rousseau made this point 68 years before Jeremy Bentham's publication of An Introduction to the Principles of Morals and Legislation (1823), where he brought forward a similar argument based on utilitarianism, which nowadays is much more well known: "The question is not Can they reason?, nor Can they talk?, but Can they suffer?" (Bentham 1823, p. 122).

According to Ryder, only pain can be of fundamental moral importance, because everything that sentient beings reject is rejected because it causes pain. Injustice, inequality and a lack of liberty are bad, according to Ryder, because they ultimately cause pain. It is pain that is common to all bad things. Things are bad, if and only if they cause suffering. Therefore, according to Ryder, a being's ability to suffer must determine whether they are morally considerable. Thus, Ryder agrees with Rousseau that sentience rather than rationality determines whether a being deserves moral consideration (Rousseau 1755; Ryder 2001). 
While Ryder focuses on pain, he considers the minimization of pain and the maximization of pleasure as prima facie the same activity (Ryder 1999, 2001). Thus, pleasure plays a role in Ryder's theory too. For instance, Ryder dismisses the (painless) killing of humans or animals, if it forecloses more future pleasure than it prevents future pain. Even though Ryder considers pleasure along with pain, he gives priority to the prevention of pain above the creation of pleasure.

Regarding his focus on the least advantaged beings, Ryder is inspired by the work of John Rawls. Rawls introduced the concept of the "veil of ignorance" (Rawls 1971), which Ryder (1999) takes over in combination with his own concept of speciesism:

The much quoted ethicist John Rawls argues that if we did not know what our position would be in society, we would be forced to choose a form of 'justice as fairness' that would guarantee basic liberties and maximize the condition of the least advantaged. He requires us to act as if we were behind a 'veil of ignorance' concerning our current sex, ethnicity, class, and status. To this list I would like to propose that 'species' be added. In other words, we should include all 'painients' (that is, all beings capable of suffering any kind of pain) in our scheme of justice, as if we did not know of which species we might find ourselves to be members. (Ryder 1999, p. 35)

Ryder accepts Rawls's argument that the best consequences are those that minimize the suffering of the most disadvantaged.

Rawls (1971) criticizes utilitarianism for not sufficiently protecting the individual, because utilitarianism considers the interest satisfaction of different individuals to be interchangeable. The rights and freedoms of an individual are, according to Rawls, not absolutely protected within utilitarianism. Utilitarianism justifies harming the interests of an individual, if this leads to the greatest overall satisfaction of interests. Rawls considers this unacceptable:

Each person possesses an inviolability founded on justice that even the welfare of society as a whole cannot override. For this reason justice denies that the loss of freedom for some is made right by a greater good shared by others. It does not follow that the sacrifices imposed on a few are outweighed by the larger sum of advantages enjoyed by many. [...] [T] he rights secured by justice are not subject to political bargaining or to the calculus of social interests. (Rawls's 1971, pp. 3-4)

Ryder partly shares Rawls's concern and argues that consciousness and the related capacity of feeling pain are inherently individual (Rawls 1971; Ryder 1999, 2010). Therefore, according to Ryder, the suffering of different individuals cannot be aggregated. Ryder takes this to imply that there is no way in which the interest satisfaction of one individual can be weighed against the interest satisfaction of others. Therefore, Ryder's painism yields other results than Singer's utilitarianism:

For painism, the agony of one counts for more than the mere discomfort of many. The question is not how many were harmed by an action, but how much was suffered by the maximum sufferer. So painism focuses on the intensity of 
suffering of each individual and not the number of sufferers. (Ryder 2010, p. 402)

This shows that Ryder accepts utilitarianism's focus on welfare, while going some way towards avoiding the implications that both Rawls and Regan are concerned about. Ryder's painism strives to protect the individual against the interests of the majority by rejecting interpersonal aggregation of welfare.

\section{Ryder's Critique Against Focusing on Sentience}

Ryder (2001, 2011) criticizes Singer's use of the word "sentience" and prefers to speak about "painience" and "painient" rather than "sentience" and "sentient." The reason for this is that Ryder considers it principally possible that a being, say an extraterrestrial, is sentient without being capable of experiencing pain. Such a being might have completely different mechanisms for avoiding danger:

I began to think of aliens who might be very sentient (e.g. experiencing emotions and able consciously to perceive and think) but not able to feel pain or distress! (Presumably they would be warned of danger by alarm buzzers and flashing red lights!) (Ryder 2011)

As Ryder conceives of the capacity to feel pain as being principally separate from sentience, he argues that the focus should be on the capacity to feel pain, rather than on sentience (Ryder 2001).

For two reasons, Ryder's criticism of the use of the word "sentience" is problematic. First, Singer $(1975,1979)$ makes it explicit that he uses the word "sentience" as a synonym for the capacity to feel pain, which is as central for him as it is for Rousseau, Bentham and Ryder. For instance, Singer (1975) says the following:

The capacity for suffering - or more strictly, for suffering and/or enjoyment or happiness - is not just another characteristic like the capacity for language or higher mathematics. [...] The capacity for suffering and enjoyment is a prerequisite for having interests at all, a condition that must be satisfied before we can speak of interests in a meaningful way. (Singer 1975, p. 7)

Singer bases moral considerability on the capacity to feel pain. Singer goes as far as claiming that without this capacity, a being would have no interests at all. While Singer often speaks about "sentience" or "consciousness" rather than about the capacity to feel pain, he clearly points out that his focus is on this latter capacity. It is for this reason that Singer cites Bentham's famous dictum that moral considerability is not based on the capacity to think or speak, but on the capacity to suffer. As Singer and Ryder substantially agree on this issue, Ryder's criticism is misguided.

The second problem concerning Ryder's criticism of the use of the word "sentience" is that the capacity to experience the world goes together with preferring certain experiences above others, and thus the capacity to suffer if what one prefers does not happen. The link between those capacities is so strong that the 
extraterrestrials Ryder imagines seem inconceivable in this world. As Holtug (1998) explains:

Trees, like guided missiles, do not really have a perspective on the world, according to which things can be good or bad for them. In other words, it cannot make a difference to them what happens to them, since they cannot desire things to go one way or the other or experience such events. (Holtug 1998, pp. 208-209)

If a being is conscious, it has an interest in what happens to it, and will show goal-directed behavior, a being needs a representation of the goal. The being must be aware of her environment, of herself, and of her preferences, and she tries to act in a way that realizes those preferences (Saidel 2009). Those preferences of beings that are capable of goal-directed behavior are based on sentience. After all, goal-directed behavior should be distinguished from merely goal-oriented behavior:

Goal-directed behavior is behavior directed towards achieving a goal whereas goal-oriented behavior is behavior oriented - say by evolution - so that if it is performed in the right environment, it will lead to a goal. (Saidel 2009, p. 38)

A rat navigating through a labyrinth in order to get hold of a piece of cheese shows goal-directed behavior. The same holds for a chimpanzee that smashes a nut between two stones in order to eat it. A plant turning the leaves towards the sun each time the sun shines on a particular part of the plant is showing goal-oriented behavior. The difference is that goal-directed behavior is based on preferences, which, in turn, are based on sentience (Saidel 2009).

Considering all this, it seems very unlikely that a being is conscious and shows goal-directed behavior, but that it does not matter for that being whether or not she realizes her goals. Ryder's counterexample lacks credibility. Therefore, that criticism against Singer and utilitarianism in general is unconvincing.

\section{Ryder's Critique Against Utilitarian Aggregation}

Ryder (1999, 2001) criticizes utilitarian aggregation, i.e., summing up and comparing the welfare of different individuals. Ryder considers suffering something utterly individual. Ryder accepts aggregation of welfare within individuals, but not aggregation between individuals. According to Ryder, due to the individual character of suffering, it is impossible to sum up the suffering of several individuals:

Consciousness, and that part of consciousness with which we are especially concerned (the experience of pain) are strictly individual. What happens to a conscious individual is the universe for that individual. Many moral schemes nevertheless consider that the sufferings of many can be aggregated. Utilitarianism is an example. (Ryder 1999, p. 36)

Utilitarianism's willingness to weigh the welfare of an individual against that of a group has inspired the well-known criticism against utilitarianism that it violates the 
"separateness of persons." A standard example is a large amphitheater in which individuals are subjected to cruel games, which seriously hurt or even kill those individuals. Provided that the public that enjoys those games is sufficiently large, it seems that the public's pleasure outweighs the individual's suffering. According to Ryder such a trade-off is in fact impossible, and therefore unjustified:

There exists a barrier between individuals through which consciousness cannot pass. However much I empathize or sympathize with your pain, I can never feel that same pain. (Ryder 1999, p. 37)

According to Ryder, interpersonal aggregation of welfare is impossible. Therefore, the value of an action that results in 100 individuals having a welfare level of $x$, is $x$ rather than a 100 times $x$. This implies that the enjoyment of the public cannot justify the suffering of the person in the amphitheater, no matter how large the public is. Provided that the suffering is worse than the enjoyment that every viewer gains by watching the game, the cruel game cannot be justified. According to Ryder, such issues should be decided by considering the suffering of the individual that suffers most.

Is Ryder's criticism against interpersonal aggregation of welfare convincing? It seems that Ryder accuses those who accept interpersonal aggregation of welfare for making a metaphysical mistake. Ryder reminds us that there is nothing like a superbeing that actually experiences the pain of several individuals. However, utilitarianism does not entail the denial of the metaphysical separateness of persons (Norcross 2009). Utilitarians would agree with Ryder that pain is strictly individual and that one can never feel another's pain. This, however, does not rule out that outcomes can be compared with regard to the pleasure and suffering that the outcomes contain and that it might be morally right to bring about the outcome that contains most welfare.

So, Ryder's metaphysical argument is unconvincing. Maybe a more charitable understanding of Ryder's concern is that those who accept interpersonal aggregation are making a moral mistake. The underlying point of critique might thus be that interpersonal aggregation of welfare is not the morally right thing to do. Let us explore whether Ryder's position that rules out interpersonal aggregation of welfare avoids counter-intuitive implications such as appealed to in the example of the amphitheater.

\section{Implications of Ryder's Painism as Compared to Utilitarianism}

Unlike deontologists such as Regan, Ryder accepts, that under certain conditions the greater benefit of an individual can justify harming another individual (Regan 1983; Ryder 1999, 2001). The conditions are:

(1) equal consideration of equal interests (no speciesism);

(2) no interpersonal aggregation of welfare, as discussed above;

(3) the greater pleasure of one person does not justify the suffering of another person (however, alleviating the greater suffering of one individual justifies causing less suffering to another individual); 
(4) no individual should be caused more suffering than the suffering of the most disadvantaged individual;

(5) no individual should be caused unbearable suffering.

On the basis of this position, Ryder rejects most uses of animals for scientific purposes and for food. At the same time, Ryder intends to avoid the criticisms that have been brought forward against deontological animal rights theories, such as Regan's, because Ryder's theory is not based on the problematic notion of moral rights. Ryder's arguments in favor of the above-mentioned criteria are mainly based on the claim that one should be most concerned with ameliorating the position of the least advantaged individual, the necessity not to cross the barrier between individuals, and the claim that pain is the ultimate bad thing that needs to be reduced.

Ryder hopes that his theory avoids implications that many might consider unjust or counterintuitive, such as in the example of the amphitheater where the enjoyment of many apparently justifies the intense suffering of one being, according to utilitarianism. It is true that Ryder's theory can avoid that particular implication. However, it has other implications that many might find equally unjust and counterintuitive. Here are three examples of what might be considered counterintuitive implications of Ryder's theory:

(1) Broken bones: imagine that you could either save one person from suffering from a broken leg or any number of people, say a million, from suffering a broken arm. Assuming that a broken leg is slightly worse than suffering a broken arm, Ryder's theory would require us to save one person from a broken leg, rather than a million persons from each having a broken arm.

(2) Bliss for many: as another example, imagine a population of beings that are all not particularly happy, but are neither suffering. There would be one way of significantly raising the level of welfare of the whole population except one, by causing a mild and brief suffering to the one person. After this brief period of mild suffering this person would continue on his usual welfare level, while the rest of the population would have a really blissful live. Ryder's theory would dismiss this option, and rather require that everyone keeps muddling on with a more or less neutral level of welfare.

(3) Saving lives: finally, imagine that a person can rescue either one person on a sinking boat or ten persons on another sinking boat. According to Ryder, dying prematurely is bad, because (and in as far as) it deprives beings of future welfare. Furthermore, dying due to a sinking boat is likely to cause emotional and physical suffering. In this case, each person's suffering and loss of welfare is equally great, or so we must assume without any further knowledge about those persons. Furthermore, according to Ryder, the welfare loss of those persons cannot be and should not be aggregated. Therefore, it follows from Ryder's theory, that there is no reason to save the ten rather than the single person even if you could do so without any further costs to yourself. According to Ryder, there is no reason to save the greater number, no matter how great that number would be. 
These kinds of examples have been discussed in the ethical debate about the significance of numbers. (Taurek 1977; Kavka 1979; Woodward 1981; Sumner 1996; Timmerman 2004; Norcross 2009). Unfortunately, Ryder does not discuss or respond to that line of criticism against his theory.

In these examples utilitarianism requires the action that minimizes suffering and seems to be more in line with the assumption that suffering is the only bad thing and pleasure is the only good thing, which Ryder shares. Furthermore, changes within the utilitarian moral theory can avoid some of the theory's alleged counterintuitive implications. Consider, for instance, the famous example of the amphitheater. It seems indeed odd that the enjoyment of the many should justify the intense suffering of one being. However, utilitarianism would only consider this justified, if there were no alternative possibilities for realizing at least as much welfare. Surely, there are ways of spending a pleasurable afternoon without causing a being to suffer. Furthermore, recently hedonism has been criticized as an account of happiness for being overly shallow. According to this criticism not every momentary pleasure, however superficial, makes us happier. Happiness, according to that line of argument, is something deeper than the sum of momentary pleasures; it is rather a matter of moods or mood propensities (Haybron 2008). Along those lines, one might wonder whether enjoying a cruel game in an amphitheater really makes the spectators any happier or, talking about welfare rather than happiness, whether it really affects their level of welfare. Maybe a less superficial account of welfare might help utilitarianism to deal with that case.

\section{Conclusion}

Richard Ryder proposed a new, improved moral theory, called painism, which is positioned in between the theories of utilitarianism and deontology, to preserve the worthwhile aspects of utilitarianism, while at the same time protecting those interests that are constitutive of an individual. Inspired by the works of Jean-Jacques Rousseau and John Rawls, painism makes three central claims: (1) the ability to feel pain determines whether a being deserves moral consideration, (2) pain is the sole moral evil, and (3) moral priority lies with improving the situation of the being that suffers most in any given situation.

Ryder has two main points of critique against Peter Singer's utilitarian moral theory. First of all, he criticizes that Singer's focus is on sentience instead of on the capacity to feel pain. Ryder argues that it would be possible for a being to be sentient, without suffering pain; therefore it would be better for Singer to focus on "painience" instead of sentience. Ryder's critique is problematic and unconvincing, not only because Singer throughout his work repeatedly emphasizes that it is the capacity to suffer that determines moral considerability, but also because one could question whether sentience without painience is even possible at all.

Ryder's second point of critique on utilitarianism is against utilitarian aggregation and trade-offs. Ryder argues that due to the fundamental individual character of suffering, it is impossible to sum up the suffering of several individuals, as if they were one individual. Utilitarianism does not, however, entail the denial of the 
metaphysical separateness of persons and many utilitarians would agree with Ryder that suffering is strictly individual and one can never feel another's pain. This doesn't rule out though that outcomes can be compared and that it could be morally right to bring about the outcome that contains the most welfare. Both of Ryder's criticisms against utilitarianism are therefore neither original nor convincing.

Furthermore, Ryder's painism is not free of counterintuitive implications itself, while utilitarianism might have more resources to deal with its own alleged counterintuitive implications than Ryder wants to acknowledge. A moral theory's implications are, to say the least, not the only criterion for its evaluation. A moral theory should also be based on a plausible and coherent foundation. It remains to be shown whether Ryder's painism, which borrows insights from different major moral theories, fares better in this respect than any of the original contenders.

Open Access This article is distributed under the terms of the Creative Commons Attribution License which permits any use, distribution, and reproduction in any medium, provided the original author(s) and the source are credited.

\section{References}

Bentham, J. (1823). An introduction to the principles of morals and legislation. Oxford: Clarendon Press. Cavalieri, P. (2010). Speciesism. In M. Bekoff (Ed.), Encyclopedia of animal rights and animal welfare (pp. 527-529). Santa Barbara, Cal. [etc.]: Greenwood Press, imprint of ABC- CLIO, LLC.

Dawkins, R. (1989). The selfish gene. Oxford: University Press.

Francione, G. L. (1996). Rain without thunder: Ideology of the animal rights movement. Philadelphia: Temple University Press.

Haybron, D. M. (2008). The pursuit of unhappiness: The elusive psychology of well-being. New York: Oxford University Press.

Holtug, N. (1998). Creating and patenting new life forms. In H. Kuhse (Ed.), A companion to bioethics (pp. 206-214). Malden: Blackwell Publishing.

Kavka, G. S. (1979). The numbers count. Philosophical Studies, 36(3), 285-294.

Kean, H. (1998). Animal rights: Political and social change in Britain since 1800. London: Reaktion Books.

Norcross, A. (2009). Two dogmas of deontology: Aggregation, rights, and the separateness of persons. Social Philosophy and Policy, 26(1), 76-95.

Rawls, J. (1971). A theory of justice. Cambridge: Belknap Press of Harvard University Press.

Regan, T. (1983). The case for animal rights. Berkeley: University of California Press.

Rousseau, J. -J. (1755) Discours sur l'origine et les fondements de l'inégalité. In CEuvres complètes III (Du contrat social; Écrits politiques) [de] Jean-Jacques Rousseau. [Paris]: Gallimard, 1964. (Bibliothèque de la Pléiade; 169).

Ryder, R. (1989). Animal revolution: Changing attitudes towards speciesism. Cambridge: Cambridge University Press.

Ryder, R. (1999). Painism: Some moral rules for the civilized experimenter. Cambridge Quarterly of Healthcare Ethics, 8, 34-42.

Ryder, R. (2001). Painism: A modern morality. London: Centaur Press, imprint of Open Gate Press.

Ryder, R. (2010). Painism. In M. Bekoff (Ed.), Encyclopedia of Animal Rights and Animal Welfare (pp. 402-403). Santa Barbara, Cal. [etc.]: Greenwood Press, imprint of ABC-CLIO, LLC.

Ryder, R. (2011). Professor Richard Ryder ARZone Interview. http://arzone.ning.com/profiles/ blogs/professor-richard-ryder-arzone. Accessed 22 Jan 2012.

Saidel, E. (2009). Attributing mental representations to animals. In R. Lurz (Ed.), The philosophy of animal minds (pp. 35-52). Cambridge: University Press.

Singer, P. (1975). Animal liberation. London: Pimlico.

Singer, P. (1979). Practical ethics. Cambridge: University Press.

Sumner, L. W. (1996). Why the numbers count. Dialogue, 35(02), 375-386. 
Taurek, J. (1977). Should the numbers count? Philosophy \& Public Affairs, 6, 293-316.

Timmerman, J. (2004). The individualist lottery: How people count, but not their numbers. Analysis, 64, $106-112$.

Woodward, J. F. (1981). Why the numbers count. Southern Journal of Philosophy, 19(4), 531-540. 